\title{
A non-circadian role for clock-genes in sleep homeostasis:a strain comparison Paul Franken ${ }^{1,3}$, Ryan Thomason ${ }^{2}$, H Craig Heller ${ }^{1}$ and Bruce F O'Hara*2
}

\author{
Address: ${ }^{1}$ Department of Biological Sciences, Stanford University, Stanford, CA, USA, ${ }^{2}$ Department of Biology, University of Kentucky, Lexington, \\ $\mathrm{KY}$, USA and ${ }^{3}$ Center for Integrative Genomics, University of Lausanne, Lausanne, Switzerland \\ Email: Paul Franken - Paul.Franken@unil.ch; Ryan Thomason - thomason.rg@pg.com; H Craig Heller - hcheller@stanford.edu; \\ Bruce F O'Hara* - bohara@uky.edu \\ * Corresponding author
}

Published: 18 October 2007

BMC Neuroscience 2007, 8:87 doi:10.1 |86//47|-2202-8-87

This article is available from: http://www.biomedcentral.com/I47I-2202/8/87

C) 2007 Franken et al; licensee BioMed Central Ltd.

This is an Open Access article distributed under the terms of the Creative Commons Attribution License (http://creativecommons.org/licenses/by/2.0), which permits unrestricted use, distribution, and reproduction in any medium, provided the original work is properly cited.
Received: 8 May 2007

Accepted: 18 October 2007

\begin{abstract}
Background: We have previously reported that the expression of circadian clock-genes increases in the cerebral cortex after sleep deprivation (SD) and that the sleep rebound following SD is attenuated in mice deficient for one or more clock-genes. We hypothesized that besides generating circadian rhythms, clock-genes also play a role in the homeostatic regulation of sleep. Here we follow the time course of the forebrain changes in the expression of the clock-genes period (per)I, per2, and of the clock-controlled gene albumin D-binding protein ( $d b p)$ during a $6 \mathrm{~h}$ SD and subsequent recovery sleep in three inbred strains of mice for which the homeostatic sleep rebound following SD differs. We reasoned that if clock genes are functionally implicated in sleep homeostasis then the SD-induced changes in gene expression should vary according to the genotypic differences in the sleep rebound.
\end{abstract}

Results: In all three strains per expression was increased when animals were kept awake but the rate of increase during the SD as well as the relative increase in per after $6 \mathrm{~h} \mathrm{SD}$ were highest in the strain for which the sleep rebound was smallest; i.e., DBA/2J (D2). Moreover, whereas in the other two strains perl and per2 reverted to control levels with recovery sleep, per2 expression specifically, remained elevated in D2 mice. dbp expression increased during the light period both during baseline and during SD although levels were reduced during the latter condition compared to baseline. In contrast to per2, dbp expression reverted to control levels with recovery sleep in D2 only, whereas in the two other strains expression remained decreased.

Conclusion: These findings support and extend our previous findings that clock genes in the forebrain are implicated in the homeostatic regulation of sleep and suggest that sustained, high levels of per2 expression may negatively impact recovery sleep.

\section{Background}

At the cellular level, circadian rhythms are thought to be generated by transcriptional-translational feedback loops made up of positively and negatively acting transcriptional regulators [1]. In mammals, the core positive ele- ments are CLOCK and NPAS2 and their obligate dimerization partner BMAL1. These transcription factors drive per and cry transcription. PER and CRY proteins, in turn, interact with CLOCK/NPAS2:BMAL1 heterodimers to inhibit their own transcription, thus constituting the 
negative feedback elements. The circuitry is clearly more complex as additional feedback loops and post-translational modifications are involved [1]. Clock genes underlie circadian rhythm generation in many tissues, but the circadian rhythm in the suprachiasmatic nucleus (SCN) is required for the manifestation of overt physiological and behavioral rhythms, and is therefore considered the master circadian pacemaker $[1,2]$.

Although the role of clock genes in generating circadian rhythms is firmly established, we and others have found that they also play a role in the homeostatic regulation of non-REM sleep (NREMS) [3-5]. This notion is based on the observation that mice deficient for one or more clock genes show an altered response to sleep deprivation (SD) and on the observation that clock-gene expression in brain areas outside the SCN, notable the cerebral cortex, is influenced by the prior occurrence of sleep and wake. For instance, the typical responses in NREMS to SD were reduced or absent in mice lacking the cry 1 and -2 (cry $1,2^{-/}$ -) [4] or bmal1 (bmal1\%) [6] genes compared to wild-type controls. The diminished NREMS variables included duration, consolidation, and EEG delta power. EEG delta power quantifies the prevalence and amplitude of delta oscillations and is widely used to index the homeostatic need for NREMS [7]. Sleep under undisturbed, baseline conditions was also altered in mutant mice. clock-mutant $\left(\right.$ clock $\left.^{\Delta / \Delta}\right)$ [8] and npas2-/[3] mice spent less time in NREMS whereas $c r y 1,2^{--[4]}$ and bmal1\% [6] mice slept more. NREMS consolidation was increased in $c r y 1,2 \%$ mice while the opposite was observed in $\operatorname{clock}^{\Delta / \Delta}[8]$ and bmal1\% [6] mice and in mice lacking albumin D-binding protein $(\mathrm{dbp} / /)$ [9]; a gene under the transcriptional control of CLOCK [10] and that also has been implicated in circadian rhythm generation [11]. Average levels of EEG delta power were reduced in $\operatorname{clock}^{\Delta / \Delta}[8], d b p^{-/-[9], ~ a n d ~ b m a l 1 \%-~}$ [6] mice and increased in $c r y 1,2 \%[4]$ mice.

Clock-gene expression in the brain, notably the cerebral cortex, depends on the sleep-wake (or rest-activity) distribution. Cortical levels of per are high at times when sleep drive is high, irrespective of the phase at which the circadian expression of per peaks in the SCN. Thus, in both nocturnal and diurnal species, per expression in the cortex is maximal in conjunction with the major waking episode [12-14]. Under conditions where the phase (methamphetamine administration, restricted feeding) or distribution (circadian splitting) of locomotor activity is altered, per expression in the cortex parallels the overt rhythm of wakefulness, while per expression in the SCN remains unaffected [13,15-17]. Consistent with these observations, our data demonstrate that per expression increases when mice are kept awake $[3,4]$. The lack or alteration of particular clock genes in the various mouse models mentioned above, changes the expression levels of other clock genes in the circuitry. For instance, basal per expression levels are decreased in $c$ lock ${ }^{\Delta / \Delta}$ mice $[10,18]$ and increased in $c r y 1,2 \%$ mice $[4,19-21]$ which corresponds to their opposing sleep phenotypes (see above). Also, the SDinduced increase in per expression is reduced in npas $2 \%$ mice [3] which suggest that NPAS2 is implicated in linking per2 expression to the sleep-wake distribution. Likewise, npas $2 \%$ mice lack circadian rhythms in cortical per2 expression despite an intact circadian organization of sleep and waking [12].

The finding that NPAS2 couples wakefulness to clock gene expression is of particular interest given the evidence that NPAS2 (and CLOCK) -mediated transcription is redox sensitive [22]. Redox sensitivity suggests that this clock gene network may be linked to cellular energy metabolism [23]. Since restoration of an optimal neural energy state has long been considered a possible function of sleep [24], this gene network might underlie a fundamental aspect of sleep homeostasis. If so, another critical gene in this network is likely to be ldha (lactate dehydrogenase A). ldha can be induced in cell culture by NPAS2, has multiple E-box sites, is a critical enzyme for neuronal energy metabolism, and utilizes NADH as a co-factor $[12,22]$. Therefore, we decided to investigate gene expression in the forebrain in greater detail over the course of a SD and after recovery sleep for the CLOCK and NPAS2 target genes per1,per2, dbp, and ldha. Futhermore, we undertook this examination of the sleep-wake dependent changes in gene expression in three inbred strains of mice known to differ in the rate at which sleep need, quantified as EEG delta power, increases during wakefulness [25]. We reasoned that if clock genes are implicated in sleep homeostasis, then the time course of changes in gene expression during a SD in these strains should vary according to the published differences in EEG delta power dynamics.

\section{Results \\ Control conditions}

Under undisturbed control conditions, forebrain levels of per 1 , per 2 , and $d b p$ expression varied both as a function of time-of-day and of genotype (2-way ANOVA factors 'genotype' and 'ZT' $P<0.0001)$. Generally, all three genes reached highest expression levels at ZT8 (post-hoc Tukey; $P<0.05$; Fig.1), but there were time-course differences. The values for $d b p$ expression were lowest at ZT1 and ZT3 and then increased throughout the light period. In contrast, the expression of per 1 and per 2 first decreased from ZT1 reaching lowest levels at ZT3 or -6 before increasing. The time courses observed here match well those previously published for most brain areas outside the SCN and for certain other peripheral tissues [16,26-28] with lowest mRNA values observed early ( $d b p$ ) or mid (subjective) day (per1, per2) and peak levels being reached around ZT8 for $d b p$ or around ZT12-14 for per1 and per2 (not assessed 

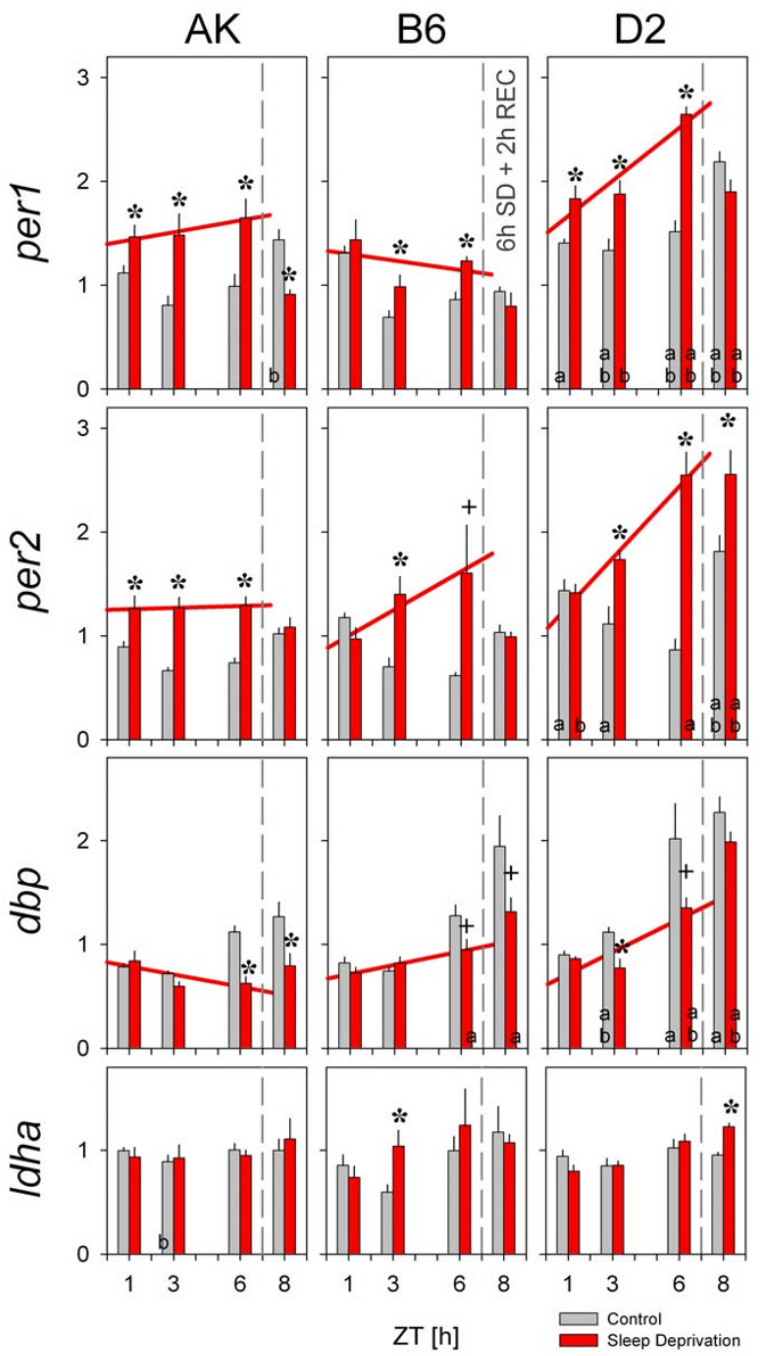

\section{Figure I}

Mean (+ISEM) forebrain mRNA levels of perl, per2, $d b p$, and Idha (top to bottom panels) for AK (left), B6 (middle) and D2 (right panels) mice after sleep deprivations (SD) of I-, 3-, and $6 \mathrm{~h}$ (red bars). All SDs started at light-onset (ZT0). Control animals (grey) were sacrificed along with the SD animals. Effects of recovery sleep on expression were assessed by allowing $2 \mathrm{~h}$ of recovery (REC) after $6 \mathrm{~h}$ SD (ZT8). perl, per2, and $d b p$, but not ldha expression, was affected by SD, genotype, and time-of-day (3-way ANOVA factors 'SD' and 'genotype': $P<0.0001$, factor 'ZT': perl $P=0.0002$, per2 $P=$ $0.004, d b p P<0.0001)$. For both per genes the SD effect differed among genotypes ('SD'-'genotype' interaction: per $I: P=$ 0.039; per2: $P=0.006$ ). Linear regression lines (red) describe the time course of mRNA changes during SD (ZTI through ZT6; see Fig.2). Asterisks and crosses mark times when SD differed from controls $(P<0.05$ and $P<0.10$, respectively; post-hoc $t$-tests). Symbols 'a' (> AK) and 'b' (> B6) mark strain differences for each time point and condition $(P<0.05$; post-hoc Tukey). here). No systematic variation in ldha expression levels was observed across the 4 time points in any strain.

Although the time-dependent changes in gene expression did not differ among the 3 inbred strains, genetic background did affect overall expression levels within the control group. With few exceptions, expression of per1, per2, and $d b p$ was higher in D2 compared to AK and B6 mice at all four time-points (post-hoc Tukey; $P<0.05$; Fig.1, summarized in Fig.2A). Elevated expression levels for D2 were maintained even during SD-conditions (Fig.2A). Genotype did not affect the level of ldha expression.

\section{Sleep deprivation}

Against this varying background the effects of enforced wakefulness on the expression of clock and clock-controlled genes was evaluated. Confirming our previous results in $\mathrm{B} 6$ mice $[3,4], 6 \mathrm{~h}$ SD increased per 1 and per2 expression and decreased $d b p$ expression in comparison to time controls (Fig.1). The present experiment allowed us to follow the time course of gene expression during the $6 \mathrm{~h} \mathrm{SD}$ and also enabled us to assess and compare the dynamics among mice of different genetic backgrounds.

SD changed the expression of these genes in the same direction in all three strains, however, significant genotype differences were observed in the dynamics and the magnitude of these changes (Figs. 1 and 2B). In AK mice per1 and per2 expression was significantly increased after only $1 \mathrm{~h}$ of SD compared to control levels at ZT1. In D2 mice only per 1 was increased after $1 \mathrm{~h}$ of $\mathrm{SD}$, and in $\mathrm{B} 6$ mice neither per 1 nor per 2 were increased by $1 \mathrm{~h}$ of SD. However, per1 and per2 mRNA in AK mice did not increase further as SD progressed whereas in D2 mice (as well as in $\mathrm{B} 6$ for per2) a progressive increase was observed from 1- to 3- to $6 \mathrm{~h} \mathrm{SD} \mathrm{(Figs.1} \mathrm{and} \mathrm{2B).} \mathrm{Forebrain} \mathrm{mRNA}$ levels of $d b p$ increased over the $6 \mathrm{~h}$ of the experiment in both control and SD groups of D2 and B6 mice, but the $\mathrm{SD}$ values tended to be lower than the control values after 3 and $6 \mathrm{~h} \mathrm{SD}$. The increase of per1, per 2 , and $d b p$ over the course of the SD was quantified by linear regression analysis which demonstrated that the rate of increase was significantly greater in D2 mice compared to AK mice (Figs.1 and 2B). The largest changes (both increases and decreases) in mRNA levels were observed after 6 h SD. For per 1 and per 2 expression the increase at this time point differed significantly among inbred strains (2-way ANOVA interaction 'genotype'-'SD': per1 $P=0.009$; per2 $P=$ $0.022)$. In $\mathrm{D} 2$ mice the per1 increase (1.8-fold, \pm 0.3 ) was larger than in B6 mice $(1.4 \pm 0.1 ; P=0.0003)$ and the per2 increase $(2.9 \pm 0.3)$ larger than in AK mice $(1.8 \pm 0.1 ; P=$ $0.0010)$. Sleep deprivation did not affect ldha expression.

The genotype specific changes in clock-gene expression during SD (Fig.2B), the genotype differences in the aver- 

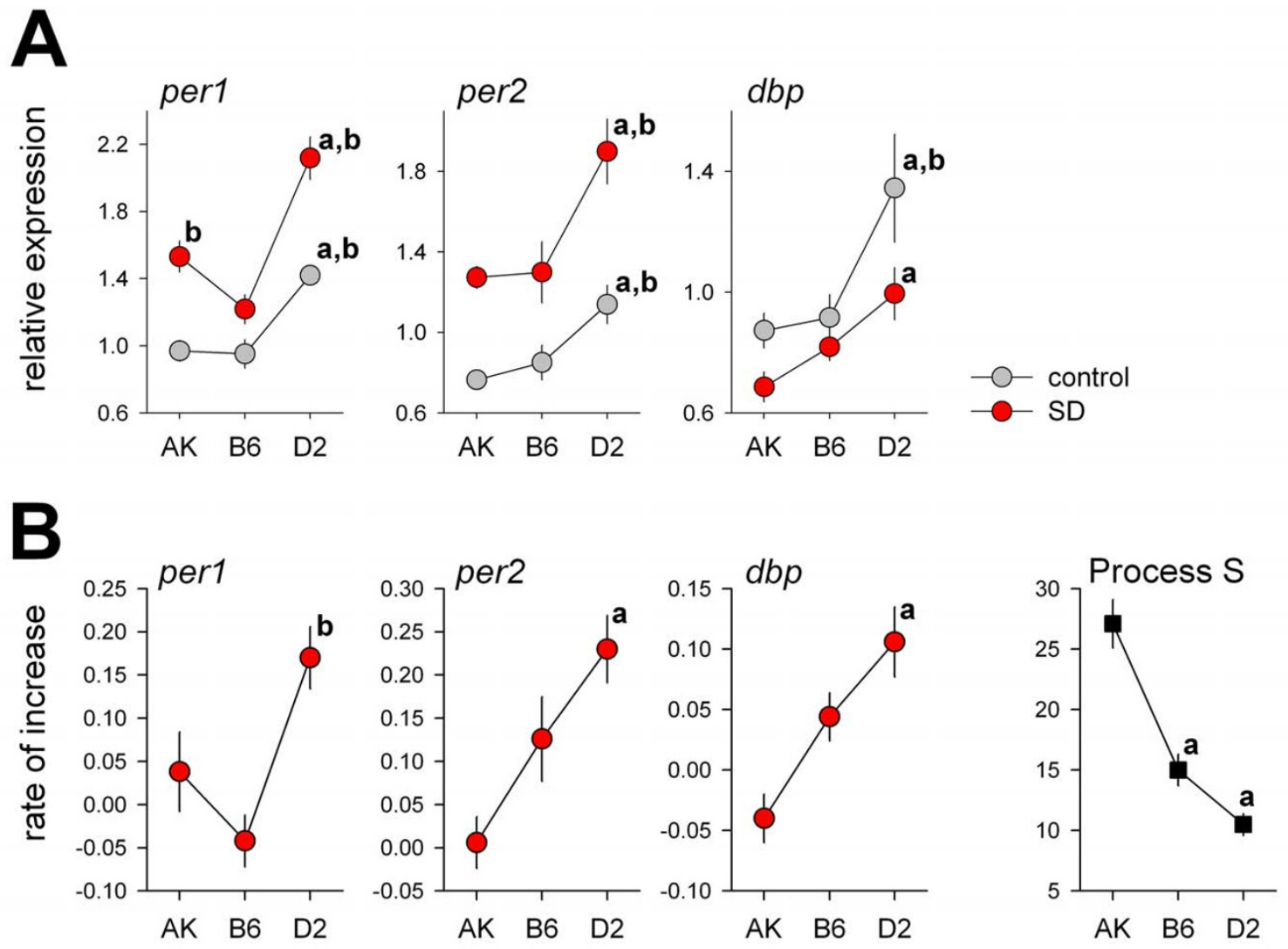

Figure 2

A) Average mRNA levels under both control (mean ZTI-6; \pm ISEM; $n=12 /$ strain; grey) and SD (mean ZTI-6; red symbols; $n$ $=12 /$ strain) conditions were generally higher in D2 mice compared to AK and B6 mice ['a' (> AK), 'b' (> B6) $P<0.05$; post-hoc Tukey]. No genotype differences were observed for Idha expression (not shown). B) Mean ( \pm ISEM; $n=12 / g e n o t y p e)$ slope of the regression lines quantifying the relationship between SD duration (I-, 3-, and $6 \mathrm{~h}$ ) and clock-gene expression (fraction/h; see Fig. I) in the forebrain of AK, B6, and D2 mice. Changes in expression were affected by genotype (2-way ANOVA: 'genotype'-'ZT' interaction: perl: $P=0.0002$; per2: $P=0.032$; $d b p: P=0.0002$ ). Slopes were steepest for $D 2$ mice and the strain distribution pattern for this phenotype seemed to negatively correlate with the increase of EEG delta power (\%/h) during wakefulness (i.e., 'Process S' in lower right panel; modified from [25]; with permission).

age expression levels during both control and SD (Fig.2A), and the larger relative increase in per1 and per 2 after $6 \mathrm{~h}$ $\mathrm{SD}$ are all opposite to the strain differences we previously reported in the dynamics of the homeostatic regulation of sleep [25]. For this phenotype the rate of increase in sleep need during wakefulness (quantified as EEG delta power during NREMS) was fastest in AK mice and slowest in D2 mice (Fig.2B). This suggests a negative correlation between the magnitude of the increase in these clock genes and the homeostatic regulation of sleep. To facilitate a direct comparison between our present and our previous study we made every effort to follow the same experimental protocol and conditions including the LD cycle, light intensity, ambient temperature, animal provider, sex and age of the mice, acclimatization time, start time and method of sleep deprivation.

\section{Recovery sleep}

Two hours of recovery sleep affected per 1 and per 2 forebrain mRNA levels in a strain specific manner (Fig.1). per1 expression sharply decreased from the levels reached at the end of the $6 \mathrm{~h}$ SD and in AK mice values reached at ZT8 even fell below control levels. A similar recovery pattern was observed for per2 expression with the exception of D2; in this strain, recovery sleep could not lower per2 mRNA levels and values remained significantly elevated compared to control. Conversely, only in D2 mice did the decrease in $d b p$ expression revert to control levels.

\section{Correlations}

The expression of all four genes studied here are regulated by CLOCK and NPAS2 through E-boxes [22,29-31] although other cis-acting elements are known to be involved; e.g., cAMP-response and DBP-binding elements 
$[11,26,29,32,33]$. Given the likelihood of shared transcriptional regulation through E-boxes, we tested expression patterns for similarities among these four genes and how these relationships were affected by the SD (Fig.3). Under both control and SD conditions the two period genes were strongly correlated sharing 63 and $42 \%$ of the variance, respectively $\left(\mathrm{R}^{2}\right.$; linear regression, $P<0.0001$; Fig.3). Other significant correlations observed during control conditions were between per 1 and $d b p\left(\mathrm{R}^{2}=0.28 ; P<\right.$ $0.0001)$ and between $d b p$ and $l d h a\left(\mathrm{R}^{2}=0.24 ; P=0.0004\right)$ expression. These relationships changed dramatically with SD; per2 expression, which was affected the most by $\mathrm{SD}$, now became correlated with that of the other 3 genes while the per1-dbp and $d b p$-ldha correlations no longer reached significance levels and the per2-dbp correlation, that was not significant during control, became equally important as the per1-per2 correlation $\left(\mathrm{R}^{2}=0.44\right.$ and 0.42 respectively, $P<0.0001 ;$ Fig. 3$)$. The SD-induced increase in the correlation coefficient between per 2 and $d b p$ expression $(-0.15$ vs. 0.50$)$ and the decrease observed for the per1-dbp correlation $(0.45$ vs. -0.12$)$ were significant $(P<$ $0.005 ; 2$-sided; $\mathrm{n}=48$ /condition). Within strains, the same relationships were observed, although they did not always reach significance levels (analyses not shown).

\section{In situ hybridization}

To gain insight into which forebrain regions contributed to the SD-induced changes in per1 mRNA levels reported above, we performed in situ hybridizations. During control conditions, forebrain expression levels were low, especially in the cerebral cortex, while expression in the cerebellum was high (Fig.4), matching previously published studies $[12,13,16,34]$. Following 6 h SD, per1 expression increased throughout the brain (Fig.4). This

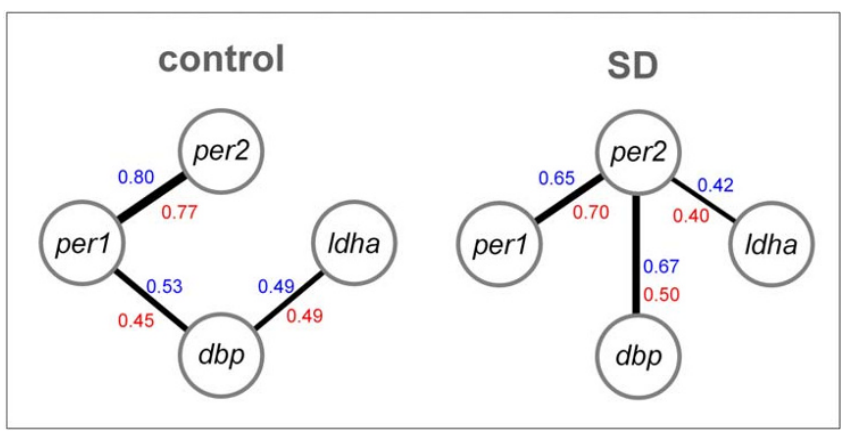

Figure 3

Significant correlations among forebrain expression levels of the four genes examined during control (left; $n=48$ ) and sleep deprivation (SD; right; $\mathrm{n}=48$ ) conditions. Only those correlations between gene pairs are indicated that remained significant after partialling out the influence of the other two. In blue the Pearson's correlation coefficients, in red the partial correlation coefficients. Line thickness corresponds to correlation strength. increase was especially pronounced in the cerebral cortex, consistent with our qPCR data (Fig.1). Within the cortex, increases were especially notable in the frontal cortex and in and around the cingulate cortex. Expression in the cerebellum was also importantly increased. Expression patterns and effects of SD described here for per1 match those of per 1 and per 2 publicly available from the Allen Institute for Brain Science website [35] (Fig.5).

\section{Discussion}

We previously found that cortical mRNA levels of the clock genes per1 and per2 were increased after SD in rats and B6 mice [4]. Here we have extended that observation in two additional inbred strains; AK and D2. Furthermore, by following the time course of these changes during SD and recovery sleep, we established that per expression changes as a function of the time-spent-awake and asleep. Such a time course is consistent with a role for these genes in the homeostatic regulation of sleep since the need for sleep increases with duration of wake and decreases with

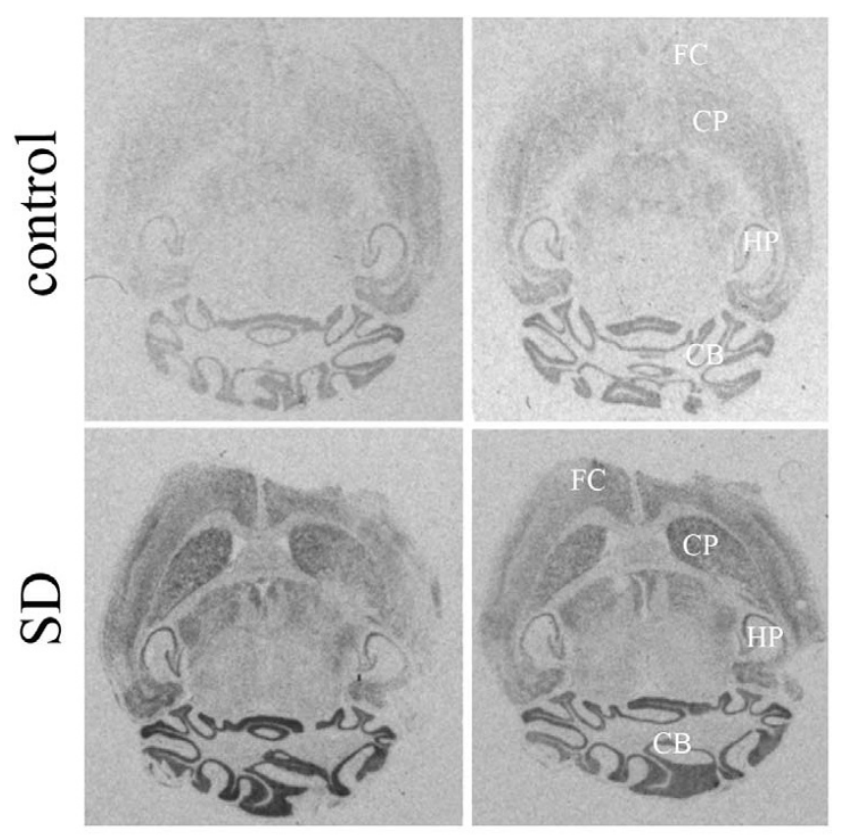

\section{Figure 4}

Representative in situ hybridizations for perl expression in two horizontal brain sections from a sleep deprived (SD, lower panels) and a control (upper panels) mouse. Following $6 \mathrm{~h}$ SD perl mRNA increased throughout the brain. This increase was especially pronounced in the cerebral cortex and cerebellum (CB), consistent with our qPCR data (Fig. I). Note the very low cortical expression in control mice which, at ZT6, spent most of the preceding $6 \mathrm{~h}$ sleeping. Within the cortex, increases were especially notable in the frontal cortex (FC) and in and around the cingulate cortex. CaudatePutamen (CP) and hippocampus (HP) are labeled for orientation. 


\section{control}
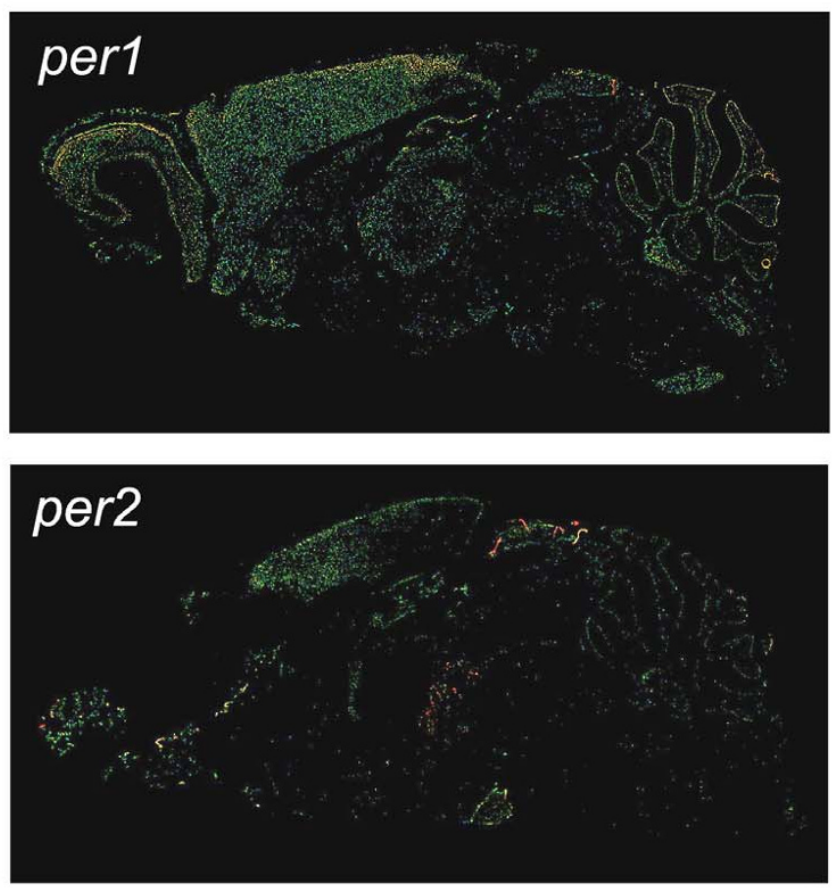

\section{sleep deprived}
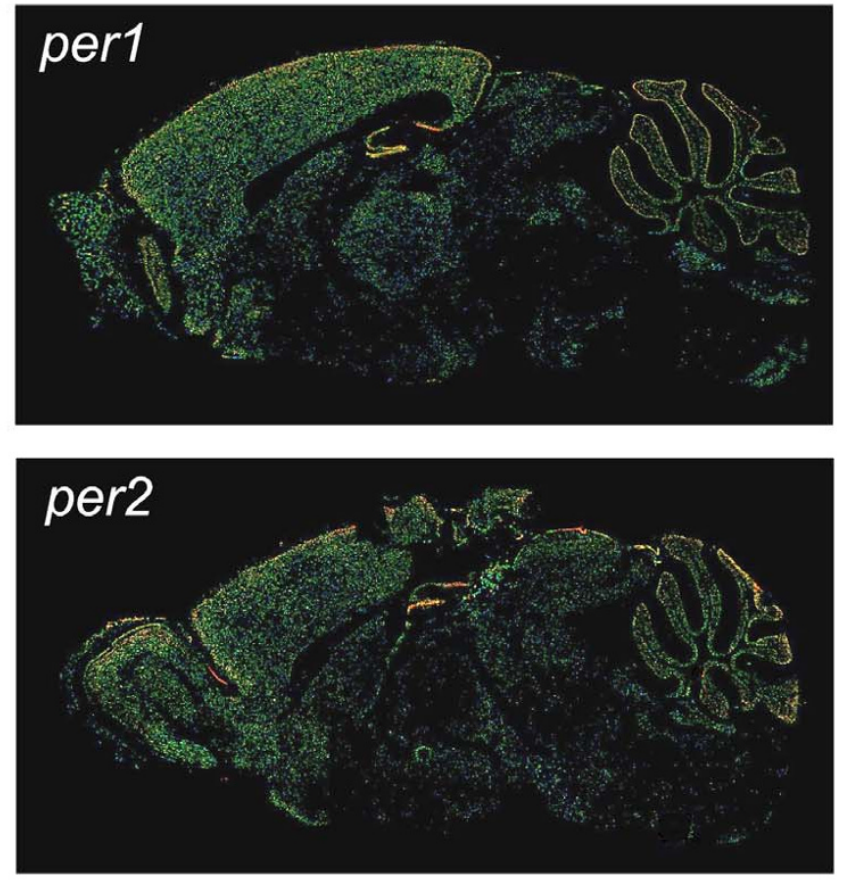
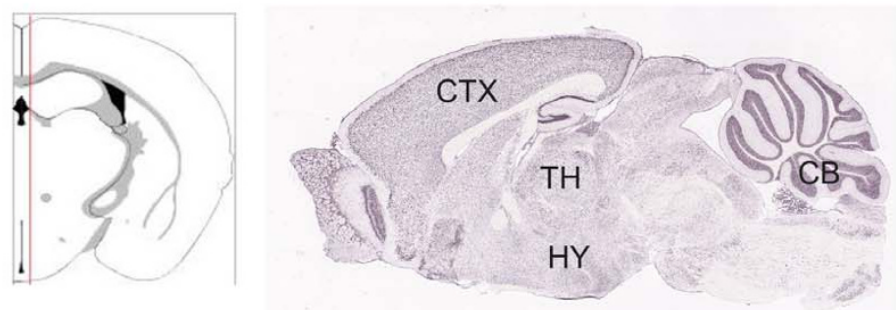

Figure 5

In situ hybridizations for perl (upper) and per2 (middle panels) expression in four sagittal brain sections from sleep deprived (SD, right) and control (left panels) mice. All sections were taken close to mid-line (see lower panel; red vertical line in coronal section indicates the plane of the sagittal sections). per was expressed mostly in cortex and cerebellum and SD induced an increase in both these areas, confirming our own perl expression data (Fig. 4). These data were taken, with permission, from the publicly available in situ studies of the Allen Institute for Brain Science [60], done in collaboration with Drs. T.S. Kilduff and J.P. Wisor of SRI International. The experimental protocol was identical to that of the $6 \mathrm{~h}$ SD in the present study; both SD and control animals were sacrificed at ZT6. ID numbers of sections: per I control: I45-0202054795 at 3625; SD: I53-0202055093 at 3825; per2 control: I40-0205056I63 at 3500; SD: I32-0205058042 at 3300. Lower right panel is the histological view (Nissl stain) of the upper right panel (perl-SD) with cerebral cortex (CTX), thalamus (TH), hypothalamus (HY), and cerebellum (CB). The presence of EEG electrodes in some mice caused cortical damage during brain removal.

duration of sleep. A novel aspect of this study is the comparison of the SD-induced changes in gene expression among three inbred strains for which the homeostatic regulation of sleep differs [25]. During both spontaneous and enforced periods of wakefulness the need for sleep, indexed by the level of EEG delta power, increased fastest in $\mathrm{AK}$, intermediate in $\mathrm{B} 6$, and slowest in D2 mice. If indeed per expression would simply parallel EEG delta power we would expect to find the largest increase in per expression after SD in AK mice and the smallest in D2. Here we found evidence for the opposite; although per expression was consistently increased with SD, this increase was modulated by genotype and was found to be highest in D2 and lowest in AK. In addition, per2 expression remained elevated during recovery sleep in D2 mice only. Thus high, sustained levels of per2 expression might negatively impact the sleep recovery process and/or expression of EEG delta oscillations during NREMS. 
An implicit assumption in our interpretation of our results is that the sleep-wake dependent changes in the expression of per1, per 2, and $d b p$ are mediated by CLOCK and/or NPAS2 induced transcription. The observation in npas $2 \%$ mice that cortical per2 expression no longer follows the circadian sleep-wake distribution [12], together with the observations that the increase in per2 expression after SD is reduced in these mice [3], and that the homeostatic response to SD is altered in $n$ pas $2 \%, c r y 1,2 \%$, and bmal1 $\%$ mice (see Introduction) strongly support this assumption. Nevertheless, expression of the genes we examined can be induced by other transcriptional regulators as well. E.g., per1 can be readily induced by cAMPresponsive element-binding protein (CREB) [29,36,37]. CREB signaling also increases during prolonged wakefulness $[38,39]$ and thus might have contributed to the SDdependent changes in per1 reported here. Another example is the close link between glucocorticoid signaling and per1 and per2 expression [40-43] through which SD, which is accompanied by an increase in plasma corticosterone levels, could have affected per expression. In fact, we found that the SD-induced increase in corticosterone levels was 3-fold higher in D2 mice compared to the other two strains (Franken et al., in preparation) consistent with the larger relative increase in per expression in this strain observed here. Evidence for an altered transcriptional regulation of the four genes during SD (compared to that during control conditions) is provided by the altered relationship between the expression patterns we report here.

The cortical expression of $d b p$ was decreased after SD confirming previously published data $[4,44]$. Given the fact that per1, per2, and $d b p$ transcription are, in part, under the same transcriptional control, these opposite effects of the $\mathrm{SD}$ are not easily explained. PER proteins are co-repressors of CLOCK and NPAS2 induced transcription. Thus, assuming that increased per expression is followed by increased PER levels within the time frame of the SD, PERmediated transcriptional repression is an obvious possible pathway by which $d b p$ expression could be decreased. In line with this assertion, we found that the decrease in $d b p$ expression to be largest in the strain with the largest increase in per expression; i.e. D2. The observation that per and $d b p$ expression were nevertheless positively correlated during the SD is, however, inconsistent with this scenario. In addition, per expression itself could be expected to decrease as well, at least the contribution of CLOCK and NPAS2 mediated transcription to the total per mRNA. Finally, the time course of the peripheral changes in $d b p$ and per expression under control conditions also doesn't support a $d b p$ suppressing role for PER. $d b p$ mRNA levels peak at ZT8 and are declining when per mRNA starts to increase [16,26-28].
The in situ hybridization studies indicated that SD induced pronounced changes in per expression in cerebellum and cerebral cortex. This is in line with our previous findings using qPCR showing that per expression was increased in the cerebral cortex but not in brainstem and hypothalamus [4] and with the per2 increase observed after SD both in cerebellum and cerebral cortex [44]. While the in situ data are limited, we observed some of the highest expression and largest increases in per1 mRNA in the most frontal area of the cortex. EEG delta power is generally higher and its increase after SD more pronounced in frontal cortex relative to other cortical areas such as occipital regions [45-47] in accordance with the concept that frontal areas in particular are affected by SD [48]. In mice lacking a functional PER1 protein (per1 ${ }^{\Delta / \Delta}$ ) EEG delta power was decreased in the frontal derivation specifically and the SD-induced increase in EEG delta power was smaller in per $1^{\Delta / \Delta}$ and per $2^{\Delta / \Delta}$ mice also only in the frontal derivation [49].

Already clear from the present data is that not all changes in forebrain per expression can be attributed to changes in the sleep-wake distribution; expression increases during the latter part of the light period while animals remain mostly asleep. This increase precedes dark onset after which maximal per expression levels are reached when mice are the most active $[16,27]$. A major adaptive advantage provided by circadian rhythms is that it allows organisms to anticipate and prepare for predictable periodic changes in the environment [50]. The anticipatory increase in per expression might be part of a molecular repertoire preparing the animal for the active period. Some types of anticipatory behavior, however, don't require an intact circadian system, as food-restriction studies have shown [51]. Moreover, clock-genes in the forebrain seem to play a permissive role in such anticipatory behaviors. For example, npas $2 \%$ mice, which have intact circadian rhythms in overt behavior, have difficulty adapting to and anticipating altered feeding schedules [17]. Besides food intake, other homeostatically regulated behaviors such as sleep seem to be similarly affected [3]. Thus, the same molecular network of transcriptional regulators that sets internal time-of-day in the SCN might, in the forebrain, track and signal time without sleep (or food). Conceptually the distinction between homeostatic and circadian processes at the molecular level thus becomes unclear. Mechanistically we proposed that changes in clock-gene expression could be tied directly to cellular energy state based mainly on the observation that CLOCK and NPAS2 mediated transcription is sensitive to redox state $[22,23]$. In this respect the lack of an effect of $\mathrm{SD}$ on ldha expression is disappointing. Although ldha has a canonical E-box and has been shown to be activated by both NPAS2 and CLOCK in a neuroblastoma cell line [22], mRNA levels of this gene were surprisingly stable 
across time-of-day, experimental condition, and genetic background.

\section{Conclusion}

We found that the expression of three circadian clock genes changes as a function of time-spent-awake and that these changes were influenced by strain. These results further indicate that circadian clock genes play a role in the homeostatic regulation of sleep. Additional evidence in support of our hypothesis has recently been obtained in humans homozygous for one of two known polymorphisms in hPer3 [52]. Based on SCN lesion experiments in rats [53] and forced desynchrony studies in humans [54] it is generally thought that homeostatic and circadian processes operate separately and have different neurophysiological substrates. Our current results underscore that, at least at a molecular level, these two processes are difficult to separate. Recent data also show that at the neuro-physiological level, SD can affect the activity of SCN neurons previously thought to be dedicated exclusively to setting internal time-of-day[55]. Finally, the present results might be of relevance for research on the biology of mood disorders. In this field there is increasing interest in the relation between clock-genes and e.g. seasonal affective disorders [56] or bipolar disorders [57]. The effects of sleep deprivation on clock-gene expression demonstrated here combined with the fact that sleep deprivation is a well known antidepressant add a molecular component to the intricate relationship between mood, circadian rhythms, and sleep (reviewed in $[58,59]$ ).

\section{Methods}

\section{Animals and Experimental Protocol}

A total of 102 mice contributed to this study. Of those, 96 were used for quantitative PCR (qPCR) analyses of per1, per2, dbp, and ldha expression in AKR/J (AK), C57BL/6J (B6), or DBA2/J (D2) mice ( $\mathrm{n}=32 /$ genotype). The remaining $6 \mathrm{~B} 6$ mice were used for in situ hybridization studies of per1. All mice were 11-week old males which were kept under a $12 \mathrm{~h}$ light/dark cycle for at least 14 days before the experiments. For the qPCR experiment half of the mice (the SD-group) were sleep deprived by gentle handling during the light phase which is their usual rest phase. The other half served as controls and were left undisturbed so they could sleep ad lib. SD started at lightonset (Zeitgeber time, ZT0). Mice of the SD-group were sacrificed after 1-, 3-, or $6 \mathrm{~h}$ SD (i.e., at ZT1, -3, or -6). A 4 th group was allowed $2 \mathrm{~h}$ of recovery sleep after $6 \mathrm{~h}$ SD (ZT8). At each time point 4 mice per genotype were taken. An equal number of control group mice were sacrificed at these 4 time points ( $n=4 /$ time-point/group/genotype). For in situ hybridization studies 3 mice were sleep deprived for $6 \mathrm{~h}$ starting at ZTO; the remaining 3 served as controls. Animals of both groups were sacrificed at ZT6.

\section{qPCR}

Brains were rapidly removed, dissected, and frozen at $70^{\circ} \mathrm{C}$. Dissection involved removal of the cerebellum and pons-medulla, followed by a single mid-sagittal cut through the remaining brain (referred to as forebrain) producing a left and a right hemisphere. Total RNA from mouse forebrains was extracted and purified using TRIzol ${ }^{\circledR}$ Reagent(Invitrogen). RNA pellets were resuspended and incubated in RNAsecure ${ }^{\mathrm{TM}}$ (Ambion). Prior to cDNA synthesis, RNA samples were treated with Turbo DNA-free ${ }^{\mathrm{TM}}$ (Ambion) to remove genomic DNA contamination, and three micrograms of total RNA were converted into first strand cDNA with Oligo $(\mathrm{dT})_{12-18}$ and Superscript II $^{\mathrm{TM}}$ (Invitrogen).

To determine gene expression profiles, cDNA of individual mice was diluted 1:4 and $2 \mu \mathrm{l}$ was aliquots were amplified in a $50 \mu$ reaction mixes containing $25 \mu \mathrm{l}$ of $\mathrm{iQ}^{\mathrm{TM}}$ SYBR $^{\circledR}$ Green Supermix (BioRad) and $0.2 \mu \mathrm{M}$ each of forward and reverse gene-specific primers. Samples were placed into 96-well 0.2 thin-wall PCR plates (BioRad), covered with optical-quality sealing tape (Biorad), and subjected to $90 \mathrm{~s}$ at $95^{\circ} \mathrm{C}$ and then subjected to 40 cycles of $15 \mathrm{~s}$ at $94^{\circ} \mathrm{C}, 60 \mathrm{~s}$ at $60^{\circ} \mathrm{C}$, and $1 \mathrm{~min}$ at $72^{\circ} \mathrm{C}$ in an iCycler $\mathrm{iQ}^{\mathrm{TM}}$ real-time Detection System (BioRad). After PCR, products were subjected to a melt curve protocol to ensure that primer-dimers and non-specific products are not present. Briefly, PCR reaction products were melted at $95^{\circ} \mathrm{C}$ for $15 \mathrm{~s}$, then the temperature was lowered to $60^{\circ} \mathrm{C}$ for $1 \mathrm{~min}$ and then the temperature increased in increments at $0.5^{\circ} \mathrm{C}$ per 10 s over 80 cycles. SYBR binds to the double-stranded PCR product until the Tm of the product is reached. Then, a sharp decline in fluorescence occurs resulting in a single peak as long as only one PCR product was amplified (gel electrophoresis of PCR products also confirmed a single band for all primer sets). The following forward and reverse primers used in this experiment were designed with Primer3, synthesized (Sigma-Genosys), and utilized as described above: per1 forward 5'-CTTGATGTGATGGCGTGTGT-3', reverse 5'-AGCTGGGGCAGTTTCCTATT-3', per2 forward 5'-ATCTCCAGGCGGTGTTGA AG-3', reverse 5'-AGGGTTACGTCTGGGCCTCT-3', $d b p$ forward 5'-AAGGCAAGGAAAGTCCAGGT-3', reverse 5'TGGGACAAGGAGGAAGTCAG-3', ld ha forward 5'-GTG CCTGTGTGGAGTGGTGT-3', reverse 5'-TGCAGCCTGGA CAGTGAAGT-3', gapdh forward 5'-CCATCAACGACCCCTTCATT-3', reverse 5'-TCTCGTGGTTCACACCCATC3', actb forward: 5'-GCCGGGACCTGACAGACTAC-3', reverse 5'-ATGGTGCTAGGAGCCAGAGC-3'.

Relative abundance of each gene was normalized to both gapdh and $a c t b$ determined by the relative standard curve method in which undiluted cDNA of all samples in each experiment were pooled and serial dilutions of the pool (stock, 1:5, 1:10, 1:100, and 1:1000) were run simultane- 
ously with the unknowns in each assay. Each unknown sample was diluted 1:4 and run in duplicate and mean expression relative to the common pool for each experiment was determined.

\section{perl in situ hybridization}

Brains were rapidly removed, frozen on dry ice, and stored at $-70^{\circ} \mathrm{C}$ until they were coated in embedding medium (Optimal Cutting Temperature Compound, Tissue Tek 4583 ) and sectionedhorizontally on a cryostat at $15 \mu \mathrm{m}$. Sections from control and SD mouse brainswere thaw mounted on micro-slides (pre-cleaned Superfrost Plus, VWR Scientific), fixed in $4 \%$ paraformaldehyde and dehydrated through an ethanol series and stored at $-70^{\circ} \mathrm{C}$.

Anti-sense per1RNA probes were made froma linearized mouse cDNA clone in pBluescript (KS-) (Stratagene, La Jolla, CA). The ${ }^{35}$ S-labeled per1 probe was transcribed from template DNA with T7 RNA polymerasein a reaction containing $5 \mathrm{mM}$ each of CTP, ATP, and GTP; $10 \mathrm{mM}$ dithiothreitol (DTT); 1X Transcription Buffer (Boehringer Mannheim, Indianapolis, IN); RNasin (Promega, Madison, WI); ${ }^{35}$ S-UTP (> 1,000 CI/mmol; NEN, Boston, MA). Probes were incubated with hydrolysis solution $(50 \mathrm{mM}$ DTT, $40 \mathrm{mM} \mathrm{NaHCO}{ }_{3}, 60 \mathrm{mM} \mathrm{Na}_{2} \mathrm{CO}_{3}$ ) for $1 \mathrm{~h}$ at $37^{\circ} \mathrm{C}$, followed by treatment with neutralization solution (50 $\mathrm{mM}$ DTT, 5\% acetic acid, $100 \mathrm{mM}$ sodium acetate). Probes were then precipitated and stored at $-70^{\circ} \mathrm{C}$.

Sections were thawed to room temperature, rehydrated, incubated with $20 \mathrm{~g} / \mathrm{ml}$ proteinase $\mathrm{K}$, and treated with acetic anhydride in $0.1 \mathrm{M}$ triethanolamine. Dehydrated sections were hybridized for $12 \mathrm{~h}$ at $60^{\circ} \mathrm{C}$ with $5 \times 10^{6}$ $\mathrm{cpm} / \mathrm{ml}{ }^{35}$ S-labeled per1 RNA anti-sense probe in hybridization buffer [ $50 \%$ formamide, $300 \mathrm{mM} \mathrm{NaCl}, 20 \mathrm{mM}$ Tris HCL (pH 7.4), $5 \mathrm{mM}$ EDTA, $10 \mathrm{mM} \mathrm{NaPO}_{4}(\mathrm{pH} \mathrm{8.0)}$, $100 \mathrm{mM}$ DTT, $10 \%$ dextran sulfate $1 \times$ Denhardt, $50 \mathrm{~g} / \mathrm{ml}$ total yeast RNA] under siliconized coverslips. Coverslips were floated off in $4 \times$ SSC at room temperature, followed by four washes in $2 \times$ SSC, DTT. Slides were rinsed in washing buffer [ $400 \mathrm{mM} \mathrm{NaCl}, 10 \mathrm{mM}$ Tris HCL (pH 7.5), $5 \mathrm{mM}$ EDTA] and incubated with $20 \mathrm{~g} / \mathrm{ml}$ RNAse A in washing buffer at $37^{\circ} \mathrm{C}$, followed by washes in $2 \times$ SSC and $0.1 \times$ SSC. Slides were dehydrated and placed on autoradiography film (Kodak Hyperfilm MP) for direct imaging to reveal areas of RNA expression resulting from annealed ${ }^{35}$ S-labeled anti-sense probes. Film was developed after 18-day autoradiography film exposure.

\section{Authors' contributions}

PF initiated and designed experiments, analyzed data, and wrote manuscript. RT conducted experiments, developed methods, and analyzed data. HCH was involved in experimental design, lab direction, and editing manuscript. $\mathrm{BFO}$, along with PF, initiated and designed experiments, analyzed data, directed all experimental work by RT, and co-wrote manuscript. All authors have read and approved the final article.

\section{Acknowledgements}

We thank Tom Kilduff and Jonathan Wisor of SRI International and Ed Lein and Carol Thompson of the Allen Institute for Brain Sciences for explanations and use of their publicly available gene expression studies presented in Figure 5. We thank Vinh Cao for technical assistance. This work was supported by National Institute of Mental Health Grant MH67752, and in part by a NSF Functional Genomics Infrastructure Award EPS-0 32295.

\section{References}

I. Lowrey PL, Takahashi JS: Mammalian circadian biology: elucidating genome-wide levels of temporal organization. Annu Rev Genomics Hum Genet 2004, 5:407-44I.

2. Yoo SH, Yamazaki S, Lowrey PL, Shimomura K, Ko CH, Buhr ED, Siepka SM, Hong HK, Oh WJ, Yoo OJ, Menaker M, Takahashi JS: PERIOD2::LUCIFERASE real-time reporting of circadian dynamics reveals persistent circadian oscillations in mouse peripheral tissues. Proc Natl Acad Sci U S A 2004, I0I(I5):5339-5346.

3. Franken P, Dudley CA, Estill SJ, Barakat M, Thomason R, O'Hara BF, McKnight SL: NPAS2 as a transcriptional regulator of nonrapid eye movement sleep: genotype and sex interactions. Proc Natl Acad Sci U S A 2006, 103 (18):71 I 8-7I 23.

4. Wisor J, O'Hara B, Terao A, Selby C, Kilduff T, Sancar A, Edgar D, Franken $\mathrm{P}$ : A role for cryptochromes in sleep regulation. $B M C$ Neuroscience 2002, 3(1):20.

5. Shaw PJ, Franken P: Perchance to dream: Solving the mystery of sleep through genetic analysis. Journal of Neurobiology 2003, 54(I): 179-202.

6. Laposky A, Easton A, Dugovic C, Walisser J, Bradfield C, Turek F: Deletion of the mammalian circadian clock gene BMALI/ Mop3 alters baseline sleep architecture and the response to sleep deprivation. Sleep 2005, 28(4):395-409.

7. Borbely AA: From slow waves to sleep homeostasis: new perspectives. Arch Ital Biol 200I, I 39(I-2):53-6I.

8. Naylor E, Bergmann BM, Krauski K, Zee PC, Takahashi JS, Vitaterna $\mathrm{MH}$, Turek FW: The circadian clock mutation alters sleep homeostasis in the mouse. J Neurosci 2000, 20(2I):8I38-8I43.

9. Franken P, Lopez-Molina L, Marcacci L, Schibler U, Tafti M: The transcription factor DBP affects circadian sleep consolidation and rhythmic EEG activity. J Neurosci 2000, 20(2):617-625.

10. Ripperger JA, Shearman LP, Reppert SM, Schibler U: CLOCK, an essential pacemaker component, controls expression of the circadian transcription factor DBP. Genes Dev 2000, I 4(6):679-689.

II. Yamaguchi S, Mitsui S, Yan L, Yagita K, Miyake S, Okamura H: Role of DBP in the circadian oscillatory mechanism. Mol Cell Biol 2000, 20(13):4773-4781.

12. Reick M, Garcia JA, Dudley C, McKnight SL: NPAS2: an analog of clock operative in the mammalian forebrain. Science 200I, 293(5529):506-509.

13. Abe H, Honma S, Namihira M, Masubuchi S, Honma K: Behavioural rhythm splitting in the CS mouse is related to clock gene expression outside the suprachiasmatic nucleus. Eur J Neurosci 200I, 14(7): II2I-II 28.

14. Mrosovsky N, Edelstein K, Hastings MH, Maywood ES: Cycle of period gene expression in a diurnal mammal (Spermophilus tridecemlineatus): implications for nonphotic phase shifting. J Biol Rhythms 200I, I 6(5):47I-478.

15. Masubuchi S, Honma S, Abe H, Ishizaki K, Namihira M, lkeda M, Honma K: Clock genes outside the suprachiasmatic nucleus involved in manifestation of locomotor activity rhythm in rats. Eur J Neurosci 2000, I 2( I 2):4206-42 I4.

16. Wakamatsu H, Yoshinobu Y, Aida R, Moriya T, Akiyama M, Shibata S: Restricted-feeding-induced anticipatory activity rhythm is associated with a phase-shift of the expression of $\mathrm{mPer} \mathrm{l}$ and mPer2 mRNA in the cerebral cortex and hippocampus but not in the suprachiasmatic nucleus of mice. EurJ Neurosci 200I, 13(6): I190-I I 96. 
17. Dudley CA, Erbel-Sieler C, Estill SJ, Reick M, Franken P, Pitts S, McKnight SL: Altered patterns of sleep and behavioral adaptability in NPAS2-deficient mice. Science 2003, 30 I(563 I):379-383.

18. Oishi K, Fukui $\mathrm{H}$, Ishida N: Rhythmic expression of BMALI mRNA is altered in Clock mutant mice: differential regulation in the suprachiasmatic nucleus and peripheral tissues. Biochem Biophys Res Commun 2000, 268(I): I64-I7I.

19. Vitaterna MH, Selby CP, Todo T, Niwa H, Thompson C, Fruechte EM, Hitomi K, Thresher RJ, Ishikawa T, Miyazaki J, Takahashi JS, Sancar A: Differential regulation of mammalian period genes and circadian rhythmicity by cryptochromes I and 2. Proc Natl Acad Sci U S A 1999, 96(21):12114-12119.

20. Griffin EA Jr., Staknis D, Weitz CJ: Light-independent role of CRYI and CRY2 in the mammalian circadian clock. Science I999, 286(5440):768-77|.

21. Okamura H, Miyake S, Sumi Y, Yamaguchi S, Yasui A, Muijtjens M, Hoeijmakers $\mathrm{JH}$, van der Horst GT: Photic induction of mPer I and mPer 2 in cry-deficient mice lacking a biological clock. Science 1999, 286(5449):2531-2534.

22. Rutter J, Reick M, Wu LC, McKnight SL: Regulation of clock and NPAS2 DNA binding by the redox state of NAD cofactors. Science 200I, 293(5529):5I0-5I4.

23. Rutter J, Reick M, McKnight SL: Metabolism and the control of circadian rhythms. Annu Rev Biochem 2002, 7I:307-331.

24. Benington JH, Heller HC: Restoration of brain energy metabolism as the function of sleep. Prog Neurobiol I995, 45(4):347-360.

25. Franken P, Chollet D, Tafti M: The Homeostatic Regulation of Sleep Need Is under Genetic Control. J Neurosci 200I, 2 I(8):26I0-262I.

26. Yamamoto T, Nakahata Y, Soma H, Akashi M, Mamine T, Takumi T: Transcriptional oscillation of canonical clock genes in mouse peripheral tissues. BMC Mol Biol 2004, 5: 18 .

27. Matsui D, Takekida S, Okamura H: Molecular oscillation of Per I and Per2 genes in the rodent brain: an in situ hybridization and molecular biological study. Kobe J Med Sci 2005, 5 I(56):85-93.

28. Yan L, Miyake S, Okamura H: Distribution and circadian expression of dbp in SCN and extra-SCN areas in the mouse brain. J Neurosci Res 2000, 59(2):291-295.

29. Travnickova-Bendova Z, Cermakian N, Reppert SM, Sassone-Corsi P: Bimodal regulation of $\mathrm{mPeriod}$ promoters by $\mathrm{CREB}-\mathrm{depend-}$ ent signaling and CLOCK/BMALI activity. Proc Natl Acad Sci U S A 2002, 99(I I):7728-7733.

30. Ripperger JA, Schibler U: Rhythmic CLOCK-BMALI binding to multiple E-box motifs drives circadian Dbp transcription and chromatin transitions. Nat Genet 2006, 38(3):369-374

31. Hida A, Koike N, Hirose M, Hattori M, Sakaki Y, Tei H: The human and mouse PeriodI genes: five well-conserved E-boxes additively contribute to the enhancement of mPerl transcription. Genomics 2000, 65(3):224-233

32. Zhang J, Dong $\mathrm{X}$, Fujimoto $\mathrm{Y}$, Okamura $\mathrm{H}$ : Molecular signals of Mammalian circadian clock. Kobe J Med Sci 2004, 50(34): $101-109$.

33. Obrietan K, Impey S, Smith D, Athos J, Storm DR: Circadian regulation of CAMP response element-mediated gene expression in the suprachiasmatic nuclei. I Biol Chem 1999 274(25): I 7748- I7756.

34. Nikaido T, Akiyama M, Moriya T, Shibata S: Sensitized increase of period gene expression in the mouse caudate/putamen caused by repeated injection of methamphetamine. Mol Pharmacol 200I, 59(4):894-900.

35. Lein ES, Hawrylycz MJ, Ao N, Ayres M, Bensinger A, Bernard A, Boe AF, Boguski MS, Brockway KS, Byrnes EJ, Chen L, Chen L, Chen TM, Chin MC, Chong J, Crook BE, Czaplinska A, Dang CN, Datta S, Dee NR, Desaki AL, Desta T, Diep E, Dolbeare TA, Donelan MJ, Dong HW, Dougherty JG, Duncan BJ, Ebbert AJ, Eichele G, Estin LK, Faber C. Facer BA, Fields R, Fischer SR, Fliss TP, Frensley C, Gates SN, Glattfelder KJ, Halverson KR, Hart MR, Hohmann JG, Howell MP, Jeung DP, Johnson RA, Karr PT, Kawal R, Kidney JM, Knapik RH, Kuan CL, Lake JH, Laramee AR, Larsen KD, Lau C, Lemon TA, Liang AJ, Liu Y, Luong LT, Michaels J, Morgan JJ, Morgan RJ, Mortrud MT, Mosqueda NF, Ng LL, Ng R, Orta G], Overly CC, Pak TH, Parry SE, Pathak SD, Pearson OC, Puchalski RB, Riley ZL, Rockett HR, Rowland SA, Royall JJ, Ruiz MJ, Sarno NR, Schaffnit K, Shapovalova NV, Sivisay T, Slaughterbeck CR, Smith SC, Smith KA, Smith BI, Sodt AJ, Stewart NN, Stumpf KR, Sunkin SM, Sutram M, Tam A, Teemer CD, Thaller
C, Thompson CL, Varnam LR, Visel A, Whitlock RM, Wohnoutka PE, Wolkey CK, Wong VY, Wood M, Yaylaoglu MB, Young RC, Youngstrom BL, Yuan XF, Zhang B, Zwingman TA, Jones AR: Genomewide atlas of gene expression in the adult mouse brain. Nature 2007, 445(7 I 24): I68-176.

36. Naruse $Y$, Oh-hashi K, lijima N, Naruse M, Yoshioka H, Tanaka M: Circadian and light-induced transcription of clock gene Per I depends on histone acetylation and deacetylation. Mol Cell Biol 2004, 24(1 4):6278-6287.

37. Tischkau SA, Mitchell JW, Tyan SH, Buchanan GF, Gillette MU: Ca2+/ CAMP response element-binding protein (CREB)-dependent activation of Perl is required for light-induced signaling in the suprachiasmatic nucleus circadian clock. J Biol Chem 2003, 278(2):7I 8-723.

38. Graves LA, Hellman K, Veasey S, Blendy JA, Pack Al, Abel T: Genetic evidence for a role of CREB in sustained cortical arousal. Neurophysiol 2003, 90(2): I I52-I I 59.

39. Cirelli C, Tononi G: Differential expression of plasticity-related genes in waking and sleep and their regulation by the noradrenergic system. J Neurosci 2000, 20(24):9|87-9|94.

40. Segall LA, Perrin JS, Walker CD, Stewart J, Amir S: Glucocorticoid rhythms control the rhythm of expression of the clock protein, Period2, in oval nucleus of the bed nucleus of the stria terminalis and central nucleus of the amygdala in rats. Neuroscience 2006, I 40(3):753-757.

4I. Balsalobre A, Brown SA, Marcacci L, Tronche F, Kellendonk C, Reichardt HM, Schutz G, Schibler U: Resetting of circadian time in peripheral tissues by glucocorticoid signaling. Science 2000 , 289(5488):2344-2347.

42. Dallmann R, Touma C, Palme R, Albrecht U, Steinlechner S: Impaired daily glucocorticoid rhythm in Perl (Brd) mice. Comp Physiol A Neuroethol Sens Neural Behav Physiol 2006, 192(7):769-775.

43. Ishida A, Mutoh T, Ueyama T, Bando $H$, Masubuchi S, Nakahara D Tsujimoto $\mathrm{G}$, Okamura $\mathrm{H}$ : Light activates the adrenal gland: timing of gene expression and glucocorticoid release. Cell Metab 2005, 2(5):297-307.

44. Cirelli C, Gutierrez CM, Tononi G: Extensive and divergent effects of sleep and wakefulness on brain gene expression. Neuron 2004, 4 I(I):35-43.

45. Huber R, Deboer T, Tobler I: Topography of EEG dynamics after sleep deprivation in mice. I Neurophysiol 2000, 84(4): $1888-1893$

46. Finelli LA, Borbely AA, Achermann P: Functional topography of the human nonREM sleep electroencephalogram. Eur I Neurosci 200I, I3(I 2):2282-2290.

47. Cajochen C, Foy R, Dijk DJ: Frontal predominance of a relative increase in sleep delta and theta EEG activity after sleep loss in humans. Sleep Res Online 1999, 2(3):65-69.

48. Horne JA: Human sleep, sleep loss and behaviour. Implications for the prefrontal cortex and psychiatric disorder. $\mathrm{Br} J$ Psychiatry 1993, 162:413-419.

49. Kopp C, Albrecht U, Zheng B, Tobler I: Homeostatic sleep regulation is preserved in $\mathrm{mPerl}$ and $\mathbf{m P e r} 2$ mutant mice. Eur J Neurosci 2002, 16(6): 1099-I 106.

50. Rusak B, Zucker I: Neural regulation of circadian rhythms. Physiol Rev 1979, 59(3):449-526.

51. Stephan FK: The "other" circadian system: food as a Zeitgeber. J Biol Rhythms 2002, I 7(4):284-292.

52. Viola AU, Archer SN, James LM, Groeger JA, Lo JCY, Skene DJ, Schantz M, Dijk DJ: PER3 polymorphism predicts sleep structure and waking performance. Current Biology 2007, 17(10.1016/j.cub.2007.01.073):

53. Trachsel L, Edgar DM, Seidel WF, Heller HC, Dement WC: Sleep homeostasis in suprachiasmatic nuclei-lesioned rats: effects of sleep deprivation and triazolam administration. Brain Res 1992, 589(2):253-26I.

54. Dijk DJ, Czeisler CA: Contribution of the circadian pacemaker and the sleep homeostat to sleep propensity, sleep structure, electroencephalographic slow waves, and sleep spindle activity in humans. J Neurosci 1995, 15 (5 Pt I):3526-3538.

55. Deboer T, Detari L, Meijer JH: Long term effects of sleep deprivation on the mammalian circadian pacemaker. Sleep 2007 30(3):257-262.

56. Partonen T, Treutlein J, Alpman A, Frank J, Johansson C, Depner M, Aron L, Rietschel M, Wellek S, Soronen P, Paunio T, Koch A, Chen P, 
Lathrop M, Adolfsson R, Persson ML, Kasper S, Schalling M, Peltonen L, Schumann G: Three circadian clock genes Per2, Arntl, and Npas2 contribute to winter depression. Ann Med 2007, 39(3):229-238.

57. Roybal K, Theobold D, Graham A, DiNieri JA, Russo SJ, Krishnan V, Chakravarty S, Peevey J, Oehrlein N, Birnbaum S, Vitaterna MH, Orsulak P, Takahashi JS, Nestler EJ, Carlezon WA Jr., McClung CA: Mania-like behavior induced by disruption of CLOCK. Proc Natl Acad Sci U S A 2007, 104(I 5):6406-64II.

58. Wirz-Justice A: Biological rhythm disturbances in mood disorders. Int Clin Psychopharmacol 2006, 2 I SuppI I:SII-5.

59. McClung CA: Circadian genes, rhythms and the biology of mood disorders. Pharmacol Ther 2007, I I 4(2):222-232.

60. Sleep Study [http://www.brain-map.org/sleep/welcome.do]

Publish with Bio Med Central and every scientist can read your work free of charge

"BioMed Central will be the most significant development for disseminating the results of biomedical research in our lifetime. "

Sir Paul Nurse, Cancer Research UK

Your research papers will be:

- available free of charge to the entire biomedical community

- peer reviewed and published immediately upon acceptance

- cited in PubMed and archived on PubMed Central

- yours - you keep the copyright

Submit your manuscript here:

http://www.biomedcentral.com/info/publishing_adv.asp
BioMedcentral 